\title{
New agriculture deans for two UC campuses
}

\section{At Davis: \\ John E. Kinsella}

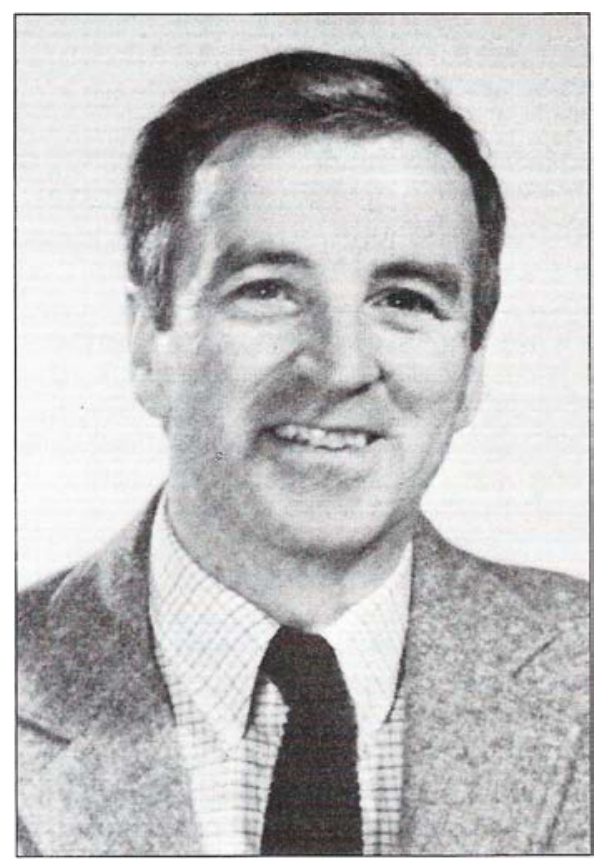

\section{"Basic biology is the keystone to progressive, environmentally sound production agriculture."}

On September 1, 1990, John E. Kinsella will succeed Charles E. Hess as Dean of the College of Agricultural and Environmental Sciences at UC Davis. As Dean, Kinsella will also direct the Davis-based programs of the university-wide Division of Agriculture and Natural Resources.

Dean Hess had held the position for 14 years when he was appointed last May as assistant secretary for science and education at the USDA. Professor Robert K. Webster of the UC Davis Department of Plant Pathology has served as Acting Dean, and will continue in that capacity through August.

Davis Chancellor Theodore Hullar recently praised Kinsella as "a very distinguished scientist with an exceptionally strong record of research in both basic and applied science."

Kinsella is eager to take his post at a time when, as he sees it, the college is "entering a period of exponential growth and innovation" to meet the needs of a changing society. In a public lecture at UC Davis earlier this year, Kinsella expressed his views on the changing societal roles of agriculture and the College. In Kinsella's view, the agricultural industry's focus is fast changing "from a preoccupation with commodity production toward a more comprehensive strategy that includes social and environmental aspects and the challenges and opportunities of a global economy."

"There are any number of agency priority lists, such as the National Initiative for Research in Agriculture, and I'm sure the various [California] commodity groups have their priority lists, too. What they all have in common, though, is a shift away from a pure commodity mentality to include more specific aspects of utilization and marketing...increasing productivity and competitiveness while reconciling production agriculture with the environment."

Kinsella believes that the public's traditional expectation for the college to create new knowledge and transmit useful technology now has an additional aspect: environmental stewardship.

"The remarkable advances emanating from the application of biotechnology play an important role in this," he says, citing new plant cultivars that require less water or resist pests and diseases. "Basic biology is the keystone to progressive, environmentally sound production agriculture and Davis must continue to be a leader in this area."

Kinsella said healso sees opportunity for industry beyond the farm gate. "The valueadded impact of agricultural products is profound, representing an enormous economic enterprise based on science, engineering, and technology," he says. "In this context, we need to be working to improve the efficiency, safety, and nutritional value of food. Consumer criteria like this - quality, nutrient content, safety, and price - are becoming increasingly important factors in production protocol."

The new dean also sees biomaterial science as an opportunity area for the college. "There is an emerging capacity to design molecules with the appropriate physical composition to create starches, proteins, polymers, and polysaccharides," he says, and UCDavis has an important place in the effort. The industry's growing demand for ingredients, rather than commodities, with specific physical properties will provide the College with new research opportunities.

As ever, the College will have an easier time finding research opportunities than finding the funds to support that research. Identifying funding sources and deciding which projects are most worthy of those funds will be among Kinsella's most difficult jobs as dean.

"The future of the College of Agricultural and Environmental Resources presents challenges, but the prospects are excellent," according to Kinsella. "Few other areas of academic endeavor are so relevant to so many pertinent aspects of society. The College is a unique and highly relevant program to the UC system." 
In 1957, a Ph.D. plant pathologist and his young family left the University of Wisconsin and headed west to Riverside, California. Although he had never been west of the Rocky Mountains, he had just accepted a position as junior nematologist at the Citrus Experiment Station of the University of California, Riverside (UCR). As he drove through mile after mile of vast, open desert, the young nematologist found himself wondering where this trip would lead.

That young nematologist was Seymour D. Van Gundy. His trip west eventually lead to his appointment in March 1990 as Dean of UCR's College of Natural and Agricultural Sciences (CNAS) and Director of Division of Agriculture and Natural Resources (DANR) programs at Riverside.

There were a number of stops along the way. Over his impressive 33-year career at UCR, Van Gundy has served as associate dean of research, Graduate Division; assistant vice chancellor for research; associate dean for research in CNAS; and chair of the Department of Nematology. At the same time, he progressed up the academic ranks to a full professorship. In 1973 he received a joint appointment to the Department of Plant Pathology. He has served as interim dean of the college since July 1988.

In recommending Van Gundy for the position, Chancellor Rosemary Schraer stated, "UC Riverside is fortunate in its current period of growth and change to have identified a wise, scholarly, and experienced academic administrator to lead one of our major collegiate units."

CNAS is unique among land-grant institutions in that it combines the agricultural and biological sciences with the physical sciences. "This structure allows for improved interdisciplinary research," says Van Gundy, "such as our programs in environmental toxicology, neurosciences, environmental engineering, and genetics/molecular biology."

Agriculture has long been a stronghold of CNAS programs and, under Van Gundy, will continue to be a top priority. "We need to reaffirm our commitment to applied agriculture in the Southern $\operatorname{Re}$ gion and address emerging concerns of the agricultural community, including environmental and natural resource issues and encroaching urbanization." To support this effort, Van Gundy has recently formed a DANR Urban and Environmental Outreach Program.

Van Gundy has identified natural resources as another priority program. "As the face of Southern California changes, there is a critical need for CNAS to respond with a program which deals with the preservation of natural resources in the face of explosive population growth and development. Traditional agricultural clientele, faced with more and more legislation placing environmental restrictions on their farming practices, demand assistance in order to comply with new regulations."

According to Van Gundy, this means increased efforts in such diverse areas as biological control, watershed management, endangered species, and conservation biology. He sees biotechnology as a key to solving the problems of both agriculture and environmental pollution.

"CNAS is one of the best research colleges of its size in the country," states Van Gundy. "We need to build on our strengths in the disciplinary sciences."

Van Gundy has earned respect as a leader, says Schraer. "He has a deserved reputation for adroit handling of difficult issues and for strong communication and support of the natural sciences and agriculture within the college and of other agricultural programs as well."

Van Gundy's leadership will be tested in the years ahead as UCR is slated to nearly double its current student population, to 18,050 by the year 2005 . For CNAS, the future depends on an aggressive stance toward recruitment of both students and faculty. "This will mean putting more emphasis on strengthening faculty and student diversity and interdisciplinary education in the sciences," says Van Gundy. "It's going to be a challenging time, but I'm looking forward to it."

\section{At Riverside: Seymour D. Van Gundy}

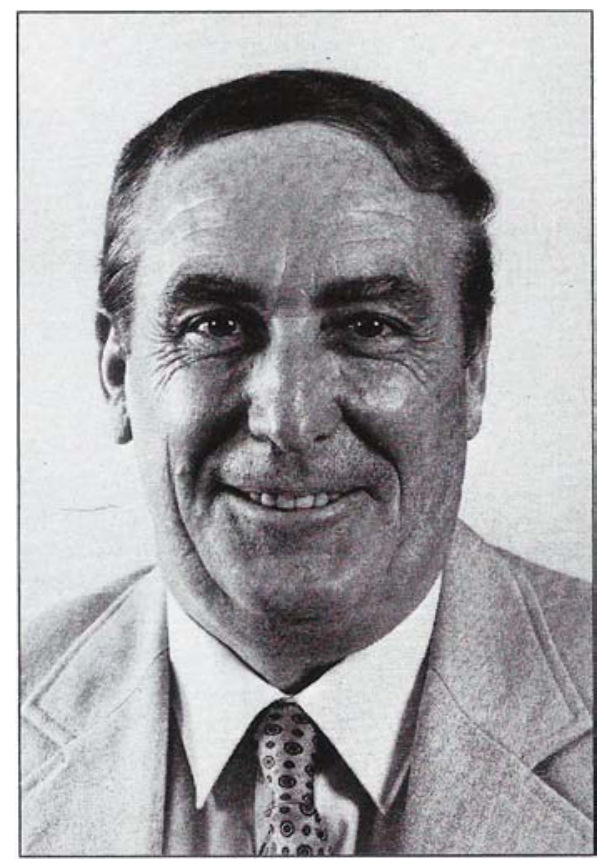

"We need to reaffirm our commitment to applied agriculture in the Southern Region." 